\title{
Female Policymakers and Educational Expenditures: Cross-Country Evidence
}

\author{
Li-Ju Chen *
}

January 11, 2009

\begin{abstract}
This paper investigates the influence of women in politics on decision-making using public educational expenditures as the outcome of interest. The results suggest that an increase in the share of female legislators by one percentage point increases the ratio of educational expenditures to GDP by 0.028 percentage points. I then consider some contexts, on which the influence of female legislators may depend. The effect of female legislators on educational policies is strengthened accounting for forms of government, but not influenced by left-wing government, electoral rules, parliamentary system and non-marriage. Moreover, this study supports the hypothesis that the identity of the legislator matters for policy.
\end{abstract}

Keywords: education, female legislator, political economy.

JEL-codes: D78, H52, J16.

\section{Introduction}

Given that political institutions play an important role in policy-making and are led by politicians of different political persuasions, it is of interest to investigate whether characteristics of these policymakers determine the type of policies. The motivation behind this study is therefore to understand whether the increasing fraction of female legislators in the OECD countries raises public educational expenditures, which the literature suggests is one of women's primary concerns. ${ }^{1}$

The influence of female legislators on educational expenditures may depend on some external contexts, such as the presence of a left-wing government, the parliamentary system, the electoral system, the form of government, the political cycle and the marriage status of women in general . An important task of this study is to control for these contexts in order to clarify the effect of women. For example, it is argued that left-wing governments expand total educational investment more than right-wing governments. The rise in the female labor force participation, which may parallel the rise in women's participation in politics, makes women more likely to favor the left. Unicameralism may enhance the influence of urban areas,

*Department Economics, Stockholm University 10691 Stockholm Sweden. I thank Professor Per Pettersson-Lidbom for his advice and support. E-mail: li-ju.chen@ne.su.se

${ }^{1}$ Data collected by the Inter-Parliamentary Union (IPU) in 1992 highlight the fact that the parliamentary committee on education is one of the areas in which women legislators are most numerous among countries in Western Europe. 
where voters demand more educational expenditures than in rural ones. While there are more policies regarding women's traditional role in the family, more women are able to enter labor market and may be encouraged to participate in politics. Electoral systems probably affect women's representation, which, in turn, affects educational expenditures. In addition, a country with a parliamentary regime may prefer a large government and support policies that benefit the majority. Investments in education may be one of the targets. The more often elections are held, the more representatives are accountable to their mandate, which may lead to less influence of females on educational expenditures. It has also been suggested that women's political preferences follow marriage status.

I find that the greater the representation of women in parliament, the higher the public educational expenditures. Specifically, my results suggest that increasing the number of female legislators by one percentage point increases the ratio of educational expenditures to GDP by 0.028 percentage points. The contextual effect of female legislators on educational policies is strengthened accounting for forms of government, but it is not influenced by the presence of a left-wing government, electoral rules, a parliamentary system, political cycle or non-marriage.

A possible explanation for these results is based on the fact that female politicians may care about women's issues more than their male colleagues. Edlund and Pande (2002) suggest that the reason women have different preferences from men is that women have default rights to children and men only get part of the right if they sign a contract for marriage where they promise to provide for their wife and children. In addition to this explanation, since the 1970s, wives are no longer legally subordinate to their husbands, and the obligation to provide for the family no longer rests solely on the husband (Edlund, Haider, and Pande (2005)).

Since women and men play different roles in society and therefore have different interests and priorities, it follows that women's interests cannot be adequately represented in decision-making by men. Ideally, representatives of groups with specific interests and perspectives should participate directly in decisionmaking processes and hold leadership roles to ensure that both the agenda of issues to be considered and the decisions subsequently made incorporate their views. This is supported by a theory that the identity of the legislator matters for policy determination if the candidates have a commitment problem (Besley and Coate (1997) and Osborne and Slivinski (1996)).

Nevertheless, even if male politicians are aware of gender differences and seek to represent women, they lack information in the same way that mainstream decision makers are unable to capture the perspectives and needs of minorities in the society. Wängnerud (2005), using parliamentary survey studies conducted in the Swedish Parliament, finds that female parliamentarians consider the duty of promoting the interests/views of women much more important than their male colleagues. Moreover, female members in the parliament have more contacts with women's organizations than male members. Since female politicians understand women as a group, they, to a greater extent than male politicians, represent the interests of women. 
The above political phenomenon has been investigated in several empirical studies. For example, Chattopadhyay and Duflo (2004) study the effect of women as policy makers through a randomized policy experiment in India. They find that the reservation of one-third of the seats for women in Panchayats (local rural self-government) in the states of West Bengal and Rajasthan has a positive effect on investment in infrastructure related to women's needs, such as drinking water and roads. Specifically, in India, gender is a relevant factor when making decisions about different kinds of investments.

Many recent studies discuss the effect of female legislators on policies, such as Besley and Case (2000) and Clots-Figureas (2007). Besley and Case (2000) assume there is an effect of female legislators on worker's compensation benefits and use female legislators as an instrument to understand the effect of these benefits on employment. Clots-Figureas (2007) uses quasi-experimental election outcomes to estimate the causal effect of politician gender. She finds that primary educational attainment is higher in urban areas of India when female political representation is higher.

Most studies of this issue, however, focus on within-country data. The contribution of my paper is therefore to analyze the effect of women's representation on educational expenditures using cross-country data and to introduce contextual effects. Some political factors, such as electoral rule and form of government, are mostly constant during the sample period and are therefore less likely to be reported in studies with individual country data.

The remainder of the paper is organized as follows. Section 2 provides the theoretical background and describes the history of female participation in politics and their policy preferences. Section 3 discusses the empirical specification and gives a description of the data. Section 4 presents the results of the paper, and discusses whether the effect of female legislators on education depends on other contexts. Section 5 concludes.

\section{Background}

The theoretical background for this study is based on models supporting the fact that the identity of a legislator matters for policy. According to the median voter model, if the candidates only care about winning the elections and commit to implementing specific policies once elected, political decisions should only reflect the preferences of the median voters (Downs (1957)), and the gender of legislators would not matter for policy outcomes. However, if the candidates could not commit to specific policies, the identity of the legislator matters for policy determination (Besley and Coate (1997) and Osborne and Slivinski (1996)). This influence on policy will be enhanced when there is increasing political representation of a certain group. According to this set of models, if politicians do not commit to implement a given set of policies once in power, a candidate's personal ideology will determine policy outcomes.

In this paper, it is assumed the representation of female politicians will support issues reflecting women's preference as long as women can vote in the elections. This line of models has been applied by Pande 
(2003), Chattopadhyay and Duflo (2004), and Svaleryd (2007). ${ }^{2}$

Turning to a description of women in politics, during 1960s-1980s, the second wave of the feminist movement, political parties across Western Europe came under pressure to adopt policies attractive to female voters and to provide greater opportunities for women's participation in the formal political arena. This was the case even in those countries where a well-organized women's movement was not developed. However, there were differences in family background among male and female legislators. According to Davis (1997), female legislators were less likely than male legislators to be married, or to have children, and were less likely to enter politics without spousal support. Even in the cases where female legislators did have children, the children tended to be older than the offspring of their male counterparts. Political careers for women, much like careers in other professions, often entailed an "either/or" choice. For this reason, female legislators tended to enter politics later in life than their male counterparts, at least in the early period of that study.

Furthermore, the role perceptions of female representatives seem to differ from their male counterparts in some ways. Thomas (1994) notes that in the United States, female delegates have been found to value aspects of their jobs related to civic duty, while men have been more inclined to highlight legislative effectiveness or status within the legislative chamber. Although women are just as likely as men to see themselves as delegates or trustees, women are more likely to see themselves as representatives of other women. Therefore, women give priority to legislation about women, and take pride in legislative accomplishments in areas of traditional concern to women. ${ }^{3}$

One possible reason why women have different preferences from men rests on the assumption that women have default rights to children and men get part of the right only if they sign a contract for marriage where they promise to provide for their wife and children (Edlund and Pande (2002)). This gives rise to the traditional division of labor between men and women, where women are more involved in functions close to the home and household. Hence, women tend to purchase goods for children and for general household consumption. As a result, they would like to choose a higher rate of saving than men, in the form of institutions such as ROSCAS (Anderson and Baland (2002)). ${ }^{4}$ The rise in the divorce rate in recent decades in Western society is suggested to lead women to prefer redistribution policies if men transfer resources to women in marriage. However, there is nothing normative about this kind of model. Increasingly, marriage is delayed or skirted entirely as witnessed by rising levels of non-marital fertility and cohabitation in the Western world. The mother is the default custodian of her children unless married, in which case, she and her husband share custody. ${ }^{5}$ Since the 1970s, wives are no longer

\footnotetext{
${ }^{2}$ Pande (2003) finds that political reservation has increased transfers to groups which benefit from the mandate. In addition, the finding also suggests that complete policy commitment may be absent in democracies. Svaleryd (2007) studies whether the degree of women's representation in Swedish local councils affects local public expenditure patterns.

${ }^{3}$ In the book "How Women Legislate", Thomas states that "... For most women, their public sphere role was only half of their job; they continued to bear the major responsibility for home and health. Given this dual role, it is not surprising that women have used their latitude to participate in the legislative arena to make private sphere issues legitimate governmental concerns."

${ }^{4}$ According to Anderson and Baland (2002), ROSCAS refers to rotating savings and credit associations.

5 "Unmarried mothers and fathers can, if mutually agreed upon, reallocate custodial rights so as to mimic the
} 
legally subordinated to their husbands, and the obligation to provide for the family no longer rests solely on the husband (Edlund, Haider, and Pande (2005)). Women may therefore favor those policies related to children and family, such as education and welfare issues, more than men when they participate in the decision-making process.

Even though party discipline may restrict female legislators' work on women's issues, it appears that they often work across party lines to the extent permissible by party leaders. As women have a sizeable presence, their policy impact is even greater because male legislators are also more likely to sponsor legislation considering the social, legal, and economic position of women than are male legislators in arenas in which women do not have a significant numeric presence. ${ }^{6}$ The dynamics of electoral competition may play a role here. If male politicians do not sponsor more legislation concerning women, female politicians might take over their vote shares from voters who pay attention to women's concerns.

Davis (1997) points out that most of the women in government leadership of countries in Western Europe are in such ministries as cultural, social welfare, women's affairs, and education once they are elected in parliament and appointed to government. 7 Moreover, there is evidence from empirical studies showing that women support educational spending once they are able to participate in politics. 8 From this point of view, I therefore take educational policy as the outcome of interest and study the influence of female politicians on decisions regarding educational expenditures. In the field of education, it seems reasonable to expect that women care about both the quantity and quality of children's education. At earlier stages of economic development, women support educational policies related to people's basic needs, such as increasing schooling accessibility and literacy rate. ${ }^{9}$ On the other hand, it is more likely that women support policies about improving quality of education after the infrastructure of compulsory education is well-established. High quality education is not only important for knowledge development, but also for overcoming long-standing inequalities. ${ }^{10}$ I therefore expect to observe a positive effect of female parliamentarians on educational expenditures.

marital situation." See Edlund, Haider, and Pande (2005).

${ }^{6}$ See Thomas (1994).

7 "... If women are to be appointed to government, then they must first be elected to parliament." See Davis (1997).

${ }^{8}$ Svaleryd (2007) shows that female legislators, relative to their male colleagues, regard education as a more important sector than elderly care in Sweden. Lott and Kenny (1999) state that the influence of women's suffrage in US may have been reflected in the large increase in educational spending, and large increases in state transfers to local governments, which spend over a quarter of their budgets on education.

${ }^{9}$ For example, Clots-Figueras (2007).

${ }^{10}$ Schwindt-Bayer (2007) points out that countries need to ensure that women are in the candidate pool by encouraging women to continue their education beyond secondary school and get degrees in professional fields that can be springboards to a political career such as a law degree, or by getting more women into the paid labor force and providing leadership training such that they can hold managerial positions. 


\section{Empirical specification and data}

\subsection{Empirical specification}

First, I consider the following empirical specification:

$$
E D U_{i, t}=\alpha+\beta F E M_{i, t}+\varepsilon_{i, t}
$$

where $i$ denotes country indices, EDU denotes public educational expenditures and FEM denotes the fraction of female legislators. Representation in the lower house rather than the upper house is used in cross-country studies of this type because in bicameral legislatures lower houses generally have more legislative power than upper houses. 11 Here I expect $\beta$ to be positive if a larger proportion of women in parliament leads to higher spending on education. There are likely to be differences across countries.

Fixed country effect estimates may therefore be needed to capture the causal impact of female legislators on educational expenditures. Nevertheless, the influence of female legislators may depend on some political factors, such as electoral rule. For example, the Nordic countries continued to elect the highest number of women to their parliaments, and the electoral system for all of these countries is proportional. Since many political factors do not vary a lot within countries, I consider group fixed effects rather than country fixed effects in order to retain sufficient information. The empirical specification thus becomes

$$
E D U_{i, t}=\alpha_{g}+\beta_{1} F E M_{i, t}+\beta_{2} \mathbf{C}_{i, t}+\beta_{3} F E M_{i, t} * \mathbf{C}_{i, t}+\varepsilon_{i, t}
$$

where $i$ denotes country indices, $\alpha_{g}$ denotes group fixed effect and $\mathbf{C}$ denotes contexts. Countries are grouped according to factors, such as geographical proximity and/or institutional proximity. Vandenbussche, Aghion, and Meghir (2006) use the same criteria to group countries. ${ }^{12}$ I also control group-specific time trends in the regression, which may exist in both the proportion of female legislators and educational expenditures. In the estimation of equation (1), I subtract the means of $F E M$ and contexts, if it is not a binary variable, for the interaction term. This provides a useful and interesting interpretation.

The contexts discussed here are: the presence of a left-wing government, electoral rule, the parliamentary system, the form of government, the political cycle length and the marriage pattern in the society.

Left-wing governments are believed to favor policies considering child-related issues and social welfare more than right-wing governments. Specifically, it has been suggested that left-wing governments, in contrast to right-wing governments, are more likely to prefer public education. In addition, the rise in female labor force participation, which may mirror the rise in women's participation in politics, makes women more likely to favor the left due to their likelihood to demand welfare policies concerning women's traditional role in the family. I therefore take left-wing government as one of the contexts that need to be controlled.

\footnotetext{
${ }^{11}$ The results using the average fraction of female parliamentarians in both the upper and lower houses are similar to the results using only the fraction of female parliamentarians in the lower house.

${ }^{12}$ Their results become statistically significant after substituting group dummies for country dummies. Statistical efficiency may provide a good reason for this.
} 
Electoral rules indicate whether one country adopts a majoritarian or other type of electoral system. In the literature, the use of proportional representation - the current system in all of the Nordic countriesis singled out as one of the most important factors that influence a high representation of women. For example, in the Netherlands and Spain, where the electoral system is proportional, the share of female parliamentarians is large: $36 \%$ in the Netherlands and 30.5\% in Spain in the end of 2007. In France, in contrast, where a majoritarian electoral system is in use, only $18 \%$ of parliamentarians are women.

According to the political science literature, one feature of unicameralism is that urban areas with large populations have more influence than sparsely populated rural areas. Since the participation rate of female labor force is higher in urban areas than that in rural areas, women in urban areas may demand more policies pertaining to children and the family once they choose to go to the labor market. Increasing numbers of policies that take care of women's traditional role in the family lead to more women being able to enter labor market. At the same time, more women may be encouraged to participate in politics. Hence, a unicameral system, which reflects more urban demands should have a positive impact on educational expenditures and may matter for the level of female legislators.

Several predictions are generated from the theoretical research on how policy outcomes are influenced by different forms of government. It has been suggested that parliamentary regimes are generally associated with larger governments, i.e. higher taxes and overall spending, than presidential regimes. Persson and Tabellini (2003) provide two possible explanations. First, in parliamentary regimes, it is easier for politicians to collude with each other at the voters' expense because of the greater concentration of powers, which results in higher rents and higher taxes. Second, parliamentary regimes need continuous confidence of the majority in the legislature to maintain their powers throughout an entire election period. Spending thus optimally becomes directed towards broad programs benefiting a majority of voters. Educational policy may be one of the targets.

Political cycle refers to the length of terms in office. It has been suggested that accountability of politicians is stronger if their term in power is shorter. In other words, policy decision may reflect the preferences of median voters rather than the preferences of politicians when elections are held more frequently. With respect to this point of view, I check whether the assumption behind this study, i.e. the identity of the legislator matters for policy, is reasonable or not.

Edlund and Pande (2002) suggest that women are more likely to support the Democratic Party in the United States following divorce based on the assumption that marriage transfers resources from men to women. Edlund, Haider, and Pande (2005) extend the analysis of Edlund and Pande (2002) by using data from a number of West European countries and other measures of non-marriage, including divorce incidence, out-of wedlock fertility, and female age at first marriage. Their findings also suggest that the rise in non-marriage causes men and women to diverge in their preferences for redistribution to children. From this point of view, an increase in non-marriage may encourage women not only to enter labor market and be self-supporting, but also to participate in the formal political arena and seek policies that deal with 
women's traditional role in family, such as investment in human capital of children.

For the purpose of clarifying contextual effect of female politicians on educational expenditure, I estimate the model by addressing only one context at a time.

\subsection{Data description}

The dataset used here covers 19 OECD countries between 1960 and 2005, and includes Australia, Austria, Belgium, Canada, Denmark, Finland, France, Greece, Ireland, Italy, the Netherlands, New Zealand, Norway, Portugal, Spain, Sweden, Switzerland, the United Kingdom and the United States.

The measure of female involvement in politics mainly comes from the IPU's survey, Women in Parliaments: 1945-1995. ${ }^{13}$ This publication lists the proportion of parliamentary seats held by women in upper and lower houses in each country. The variable FEM is set equal to the proportion of women in the lower chamber. Figure 1 presents the fraction of female legislators in each country from 1960 to 2005 at 5 -year intervals. Nordic countries have a marked increase in the number of women serving in parliament over this period, while most of the Southern European countries have a relatively flat pattern.

Furthermore, data on public educational expenditures as a percentage of GDP, which is named $E D U$ here, between 1950 and 1995 at 5-year intervals is obtained directly from VAM (2006). They rely on Unesco's Statistical Yearbook (1999), which provides data on public expenditures between 1970 and 1995, and construct the early part of the series by working backward through previous Yearbooks. The series after 1995 is collected from Education at a Glance 2006 published by OECD, which is also based on the survey by Unesco. ${ }^{14}$ Figure 2 presents the ratio of total public educational expenditures to GDP in each country. In Belgium and France, there is a relatively stable ratio of educational spending to GDP, while in Portugal and Greece there is a continuous increase in this ratio over time. In general, all countries invest less than $10 \%$ of their GDP in education.

Though not always true for every country, there are some interesting common patterns comparing Figure 1 with Figure 2. Greece, Portugal, and Switzerland experienced an increase in both the representation of women in politics and in educational investments over the sample period. Furthermore, as the fraction of female legislators in Ireland, Italy, and Norway decreased in late 1990s, there is a comparable drop in educational expenditures as a percentage of GDP in these three countries. These trends suggest a positive correlation between female legislators and educational investment.

In addition to using educational expenditures as a percentage of GDP as the dependent variable, which captures the relative extent of country's investments in education, this study also uses total public educational expenditures per capita as another dependent variable, which helps understand the quantitative effect of female legislators on educational spending. Figure 3 presents total public educational expenditures per capita at constant prices in 2000 USD, obtained by multiplying the ratio of total public educational

\footnotetext{
${ }^{13}$ The series after 1995 is collected from the website of IPU.

${ }^{14}$ Data provided in this edition is only through 2003. I obtain the data for 2005 by assuming the growth rate of educational expenditures from 2003 to 2005 is the same as that from 2000 to 2003 in each country.
} 
expenditures to GDP by real GDP per capita. ${ }^{15}$ The figure shows a long-run linear growth pattern of expenditures in most countries, except the Netherlands.

Data on the presence of a left-wing government are obtained from Mapping Policy Preferences: Estimates for Parties, Electors, and Governments 1945-1998 and Mapping Policy Preferences II: Estimates for Parties, Electors, and Governments in Eastern Europe, European Union and OECD 1990-2003. Education expansion is one of the criteria deciding the right-left position of each party in both datasets. ${ }^{16}$ I calculate the percentage of seats occupied by left-wing parties in each election to represent the intensity of left-wing government.

I collected data on electoral rules and forms of government from Persson and Tabellini (2003). Majoritarian is an indicator for electoral rules, which equals 1 if all the lower house is elected under plurality rule and 0 otherwise. ${ }^{17}$ Presidential is a binary variable to denote forms of government, with the value 1 in presidential regimes and 0 otherwise. ${ }^{18}$ There are only two countries belonging to presidential regime in this study, Switzerland and the United States. Unicameral is a binary variable referring to parliamentary system. ${ }^{19}$

Term represents the time interval between elections, which is used to represent the political cycle and is obtained from the IPU survey data. It varies across the sample period among countries, except for New Zealand, Norway, Switzerland, and the US. ${ }^{20}$ In countries where there are frequent elections, the value of Term is smaller. Non-marriage is represented by Divorce, which refers to the crude divorce rate reported in the Demographic Yearbook issued by United Nations.

\section{Results}

\subsection{Baseline results}

Estimation of equation (1) without the controls for political factors is reported in Table 1. When country dummies are included, increasing female legislators by one percentage point increases the ratio of educational expenditures to GDP by 0.029 percentage points. ${ }^{21}$ This effect is statistically significant. In consideration of results driven by systematic differences, I include group dummies instead and present the

\footnotetext{
${ }^{15}$ The data on real GDP per capita at constant prices in 2000 USD are collected from Penn World Table 6.2.

${ }^{16}$ Education expansion in these dataset considers the need to expand and/or improve educational provision at all levels, and excludes technical training.

${ }^{17}$ Persson and Tabellini (2003) only consider legislative elections in lower house. The value of Majoritarian equals 0 if the system is either strict proportionality or mixed.

${ }^{18}$ According to Persson and Tabellini (2003), most semi-presidential and premier-presidential systems are classified as parliamentary. Countries are categorized as having a presidential regime if the existence of a government is without a confidence requirement. For example, France is a parliamentary regime since the legislature has an exclusive and unrestricted right of censure, even though the president is elected directly.

${ }^{19}$ Most of the countries examined had a stable parliamentary system during the sample period except for Spain and Sweden. Spain switched from a unicameral system to a bicameral system in 1977, and Sweden switched from a bicameral system to a unicameral system in 1970 .

${ }^{20}$ Term is fixed at 3 years in New Zealand, 4 years in Norway, 4 years in Switzerland, and 2 years in the US.

${ }^{21}$ Since there are 19 countries in the sample and only 10 observations in each country, it has been suggested to ignore country trends when country dummies are included.
} 
results in column (2). The standard errors are smaller in the case that includes group dummies. In other words, group dummies keep more information and therefore provide better estimation.

As shown in column (2), female legislators have a positive impact on educational expenditures. However, group-specific time trends should be included because of an increasing pattern in the proportion of female legislators across countries. Column (3) provides the results including group-specific trends, and the results are closer to the results with country dummies in column (1). Nonetheless, those factors which influence the decision of educational expenditures in individual countries should also be at work once group dummies are included. I expect both the educational expenditures and political opportunities available to women to be affected by the overall level of social and economic development. Demographic factors, such as the proportion of the population under age 25 or above age 65 , influence the allocation of government budget to education. More women in politics may reflect higher female participation rate in labor market and increasing attainment rate of women in higher education as well. In consideration of the above, I add real GDP per capita, fraction of population under age 25 , fraction of population above age 65 , female labor participation rate and lagged female attainment rate in higher education as controls when including group dummies. The results are presented in column (4). The group dummies are jointly significant with a p-value of 0 . The result is very encouraging in this respect because the coefficient is consistent with the expectation. Increasing the fraction of female legislators by one percentage point increases the ratio of educational expenditures to GDP by 0.028 percentage points. In other words, the demand for education by legislators increases as the proportion of female legislators increases.

Model results with total public educational expenditures per capita as the dependent variable are presented in columns (5)-(8). In column (8), a 1\% increase in GDP per capita raises total public educational expenditures per capita by $1 \%$, which implies that education is a normal good in developed countries. The effect of female legislators on educational expenditures is positive and statistically significant when controlling for this overall income effect. Total public educational expenditures per capita increases by $0.43 \%$ when the fraction of female legislators increases by one percentage point. ${ }^{22}$

\subsection{Contextual effects of female legislators on educational expenditures}

Though there is evidence of a positive effect of female legislators on educational expenditures, does such an effect depend on other contexts? This section discusses the effect of different contexts on educational expenditures in order to clarify the effect of female legislators. Table 2 presents the summary of these contexts across countries.

\footnotetext{
${ }^{22} \mathrm{I}$ have also examined the effect of female legislators on different levels of education using the same empirical specification. The results show that increases in female legislators are more likely to raise investments in primary and secondary education, while they also yield relevant positive influence on the investment in tertiary education.
} 


\subsubsection{Does a left-wing government prefer more education?}

Estimation of equation (1) with the control for left-wing government is reported in Table 3. Columns (1) and (4) replicate the results from columns (4) and (8) in Table 1. I take these as the baseline results. In all the regressions, I control for group dummies and group specific trends. ${ }^{23}$ The results reveal that a left-wing government per se does not impact the decisions on educational expenditures. In columns (2) and (5) female legislators maintain a significant and positive effect on educational spending, where the extent is closer to the baseline result. I add the interaction term of left-wing government and female legislators in columns (3) and (6). Given that the mean value of left-wing government in the sample is 0.62 , an increase in the fraction of female legislators by one percentage point increases the ratio of educational expenditures on GDP by 0.05 standard deviations from the mean level of left-wing intensity. This effect is significant based on the joint test. Left-wing governments distribute more net money to education given the mean level of female legislators, even though this effect is not significant.

\subsubsection{Does electoral rule matter?}

Estimation of equation (1) with a control for electoral rule is reported in Table 4. In general, results in columns (2) and (5) show that effect of female legislators on educational expenditures is irrelevant, while electoral rule does play a role in educational investments. The negative effect of plurality rule may reflect less impact on women's representation in politics rather than proportionality rule, which is likely to lead to lower spending on education. To investigate whether the effect of female legislators on education is strengthened by proportional representation, I include the interaction between female legislators and electoral rule. The interaction effect of female legislators and electoral rule is not significant, which indicates that electoral arrangements do not strengthen women's influence on educational policies. It may also imply that the fraction of female legislators share the same information as electoral rules since the partial effect of female legislators is insignificant. Nevertheless, electoral rules per se have no effect on educational expenditures.

\subsubsection{Does the parliamentary system matter?}

Estimation of equation (1) with the controls for having a parliamentary system is reported in Table 5. In general, the joint tests point out that a parliamentary system has no influence on educational expenditures as percentage of GDP, but is relevant to total educational spending. On the other hand, the representation of female legislators has a positive and significant effect on educational expenditures. Moreover, this positive effect of female legislators does not depend on which parliamentary system is adopted within a country.

\footnotetext{
${ }^{23}$ The same structure applies to all of the following tables.
} 


\subsubsection{Does government form matter?}

The estimation of Equation (1) with the control for government form is reported in Table 6. The influence of presidential regime on educational expenditures is significant and negative, which supports the view in the literature that parliamentary regimes usually raise spending directed towards broad programs. Including the interaction of female politicians and presidential regime gives a positive and significant effect of female legislators on educational expenditures. One country is more likely to have an honest government when its government is a presidential regime rather than a parliamentary regime. The allocation of the government budget may therefore be more effective, and flow into the chapters that concern women more. Hence, having more women in politics increases the weight of educational investments and gives a larger net effect of female legislators if the government is a presidential regime. Moreover, even though a presidential regime has a negative effect on educational expenditures, the effect becomes positive when the parliament introduces more female legislators than average.

\subsubsection{Does the length of the political cycle matter?}

Estimation of equation (1) with the control for the length of the political cycle is reported in Table 7 . In columns (2) and (5), the length of the political cycle has no effect on educational policy, while female parliamentarians have a positive and significant effect on educational investments. The same conclusion is obtained from the joint tests in columns (3) and (6), where the interaction term is included. This implies that the policy decision is determined by the preferences of women in politics rather than the preferences of median voters, which supports the assumption behind this study, i.e., the identity of the legislator matters for policy.

\subsubsection{Does non-marriage matter?}

The estimation of Equation (1) with the control for non-marriage is reported in Table 8. In general, results in columns (2) and (5) show that effect of female legislators on educational expenditures is relevant after controlling for the divorce rate. Moreover, the divorce rate is also positively correlated with government expenditures on education, which is likely to reflect female voters' preferences. Since the divorce rate and women's political preferences are thought to be linked, I include the interaction of female legislators and divorce rate. The joint tests in columns (3) and (6) show that female legislators have a relevant impact on spending in education. Although the interaction term is not significant, the positive effect indicates that the gender differential implications of non-marriage may turn into the provision of education to children.

\section{Conclusion}

The purpose of this paper is to investigate the influence of women's participation in politics on decisionmaking. I take educational expenditures as the outcome of interest. The contribution of this study is to 
investigate the effect of female legislators on educational expenditures by cross-country data, while most of the previous literature studying effect of female legislators on policies is based on within-country data. Moreover, I consider the political contextual effect on female legislators, which is less likely to be contained in studies with individual country data.

The baseline results suggest that the greater the representation of women in parliament, the higher the educational expenditures as percentage of GDP and the higher the educational expenditures per capita. In addition, the effect of female legislators on educational policies may depend on some contexts, such as the presence of a left-wing government, electoral rules, parliamentary system, government form, the length of the political cycle, and rates of non-marriage. Although electoral rules have been believed to be the force behind the increasing representation of women, this factor does not strengthen or weaken the effect of female legislators on educational expenditures. Including the variable "left-wing government" in the regression does not influence the effect of female legislators. Actually, more female legislators results in higher educational expenditures given the government is at the mean level of left-wing intensity. Left-wing governments allocate more money to education in net given the mean level of female legislators, although the effect is not significant. Controlling for a parliamentary system gives a positive and significant effect of female legislators. For government forms, the results show that the proportion of female legislators is again relevant to educational expenditures. Even though a presidential regime has a negative effect on educational expenditures, the effect becomes positive when the parliament introduces more female legislators than average. I further check whether the assumption behind this study is reasonable or not. The results demonstrate that accountability of politicians does not influence educational policy decisions, which supports the assumption that the identity of the legislator matters for policy. Since it has been suggested that women's political preferences follow marriage status, I check whether an increase in the divorce rate strengthens women's influence on educational policies. The effect of female legislators is robust.

This study emphasizes the effect of female legislators on educational policies on a cross-country basis. It would be interesting, however, to look also at the effect of female legislators on other type of policies, such as social welfare and health. Consequently, this may constitute an area for future research of women's impact on the economy through politics.

\section{References}

[1] Anderson, Siwan and Jean-Marie Baland (2002), "The Economics of Roscas and Intrahousehold Resource Allocation", Quarterly Journal of Economics, 117, 3, 963-995.

[2] Barro, Robert J. and Jong-Wha Lee (2001), "International Data on Educational Attainment: Updates and Implications", Oxford Economic Papers, 53, 541-563. 
[3] Berkman, Michael B. and Robert E. O'Connor (1993), "Do Women Legislators Matter? Female Legislators and State Abortion Policy", American Politics Research, 21, 1, 102-124.

[4] Besley, Timothy and Stephen Coate (1997), "An Economic Model of Representative Democracy", Quarterly Journal of Economics, 112, 1, 85-114.

[5] Besley, Timothy and Anne Case (2000), "Unnatural Experiments? Estimating the Incidence of Endogenous Policies", The Economic Journal, 110, 467, 672-694.

[6] Budge, Ian, Hans-Dieter Klingemann, Andrea Volkens, Judith L. Bara, and Eric Tanenbaum (2001), "Mapping Policy Preferences: Estimates for Parties, Electors, and Governments 1945-1998", Oxford University Press.

[7] Chattopadhyay, Raghabendra and Esther Duflo (2004), "Women as Policy Makers: Evidence from a Randomized Policy Experiment in India", Econometrica, 72, 5, 1409-1443.

[8] Clots-Figueras, Irma (2007), "Are Female Leaders Good for Education? Evidence from India", presented at the Royal Economic Society's 2006 Annual conference at the University of Nottingham.

[9] Davis, Rebecca Howard (1997), "Women and Power in Parliamentary Democracies: Cabinet Appointments in Western Europe, 1968-1992 (Women and Politics)", University of Nebraska Press.

[10] Dollar, David, Raymond Fisman, and Roberta Gatti (2001), "Are Women Really the "Fairer" Sex? Corruption and Women in Government", Journal of Economic Behavior and Organization, 46, 4, 423-429.

[11] Downs, Anthony (1957), "An Economic Theory of Political Action in a Democracy", Journal of Political Economy, 65, 2, 135-150.

[12] Edlund, Lena, Laila Haider, and Rohini Pande (2005), "Unmarried Parenthood and Redistributive Politics", Journal of the European Economic Association, 3, 1, 95-119.

[13] Edlund, Lena and Rohini Pande (2002), "Why Have Women Become Left-Wing? The Political Gender Gap and the Decline in Marriage", Quarterly Journal of Economics, 117, 3, 917-961.

[14] Heston, Alan, Robert Summers, and Bettina Aten, Penn World Table Version 6.2, Center for International Comparisons of Production, Income and Prices at the University of Pennsylvania, September 2006.

[15] Kanter, Rosabeth Moss (1977), "Some Effects of Proportion on Group Life: Skewed Sex Ratios and Response to Token Women", American Journal of Sociology, 82, 5, 965-990.

[16] Klingemann, Hans-Dieter, Andrea Volkens, Judith L. Bara, Ian Budge, and Michael D. McDonald (2006), "Mapping Policy Preferences II: Estimates for Parties, Electors, and Governments in Eastern Europe, European Union and OECD 1990-2003", Oxford University Press. 
[17] Levitt, Steven D. (1996), "How Do Senators Vote? Disentangling the Role of Voter Preferences, Party Affiliation, and Senator Ideology", American Economic Review, 86, 3, 425-441.

[18] Lott, John R. and Lawren W. Kenny (1999), "Did Women's Suffrage Change the Size and Scope of Government?", Journal of Political Economy, 107, 6, 1163-1198.

[19] Osborne, Martin J. and Al Slivinski (1996), "A Model of Political Competition with CitizenCandidates", Quarterly Journal of Economics, 111, 1, 65-96.

[20] Pande, Rohini (2003), "Can Mandated Political Representation Increase Policy Influence for Disadvantaged Minorities? Theory and Evidence from India", American Economic Review, 93, 4, 1132-1151.

[21] Persson, Torsten and Tuido Tabellini (2003), "The Economic Effects of Constitutions", MIT Press.

[22] Schwindt-Bayer, Leslie A. (2007), "Female Legislators and the Promotion of Women, Children, and Family Policies in Latin America", manuscript prepared as a background paper for UNICEF's State of the World's Children Report 2007.

[23] Svaleryd, Helena (2007), "Women's Representation and Public Spending", IFN Working Paper, No. 701.

[24] Thomas, Sue (1994), "How Women Legislate", Oxford University Press.

[25] Vandenbussche, Jerome, Philippe Aghion, and Costas Meghir (2006), "Growth, Distance to Frontier and Composition of Human Capital", Journal of Economic Growth, 11, 2, 97-127.

[26] Wängnerud, Lena (2000), "Representing Women", in Esaiasson, P. \& Heidar, K. Beyond Westminster and Congress: the Nordic Experience, Columbus: Ohio State University Press, 132-154.

[27] Wängnerud, Lena (2005), "Testing the Politics of Presence Empirically: Women's Representation in the Swedish Riksdag", Scandinavian Political Studies, 23, 1, 67-91. 
Figure 1: The fraction of female legislators

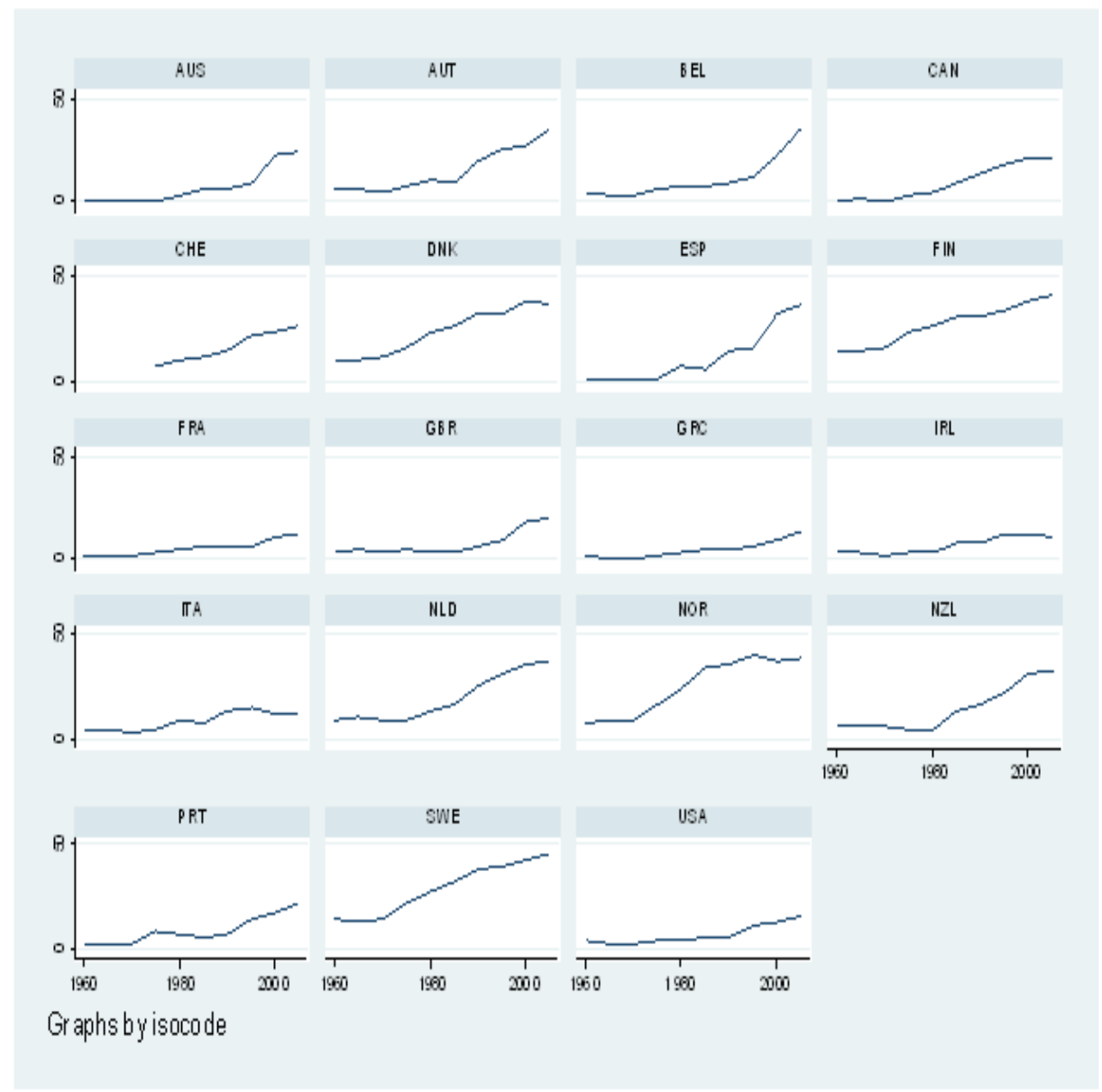

Note: 1. $\mathrm{x}$-axis is year, and y-axis is percentage. 2. Country isocodes are "AUS" for Australia, "AUT" for Austria, "BEL" for Belgium, "CAN" for Canada, "DNK" for Denmark, "FIN" for Finland, "FRA" for France, "GRC" for Greece, "IRL" for Ireland, "ITA" for Italy, "NLD" for Netherlands, "NZL" for New Zealand, "NOR" for Norway, "PRT" for Portugal, "ESP" for Spain, "SWE" for Sweden, "CHE" for Switzerland, "GBR" for United Kingdom, and "USA" for United States. 
Figure 2: The ratio of total public educational expenditures to GDP

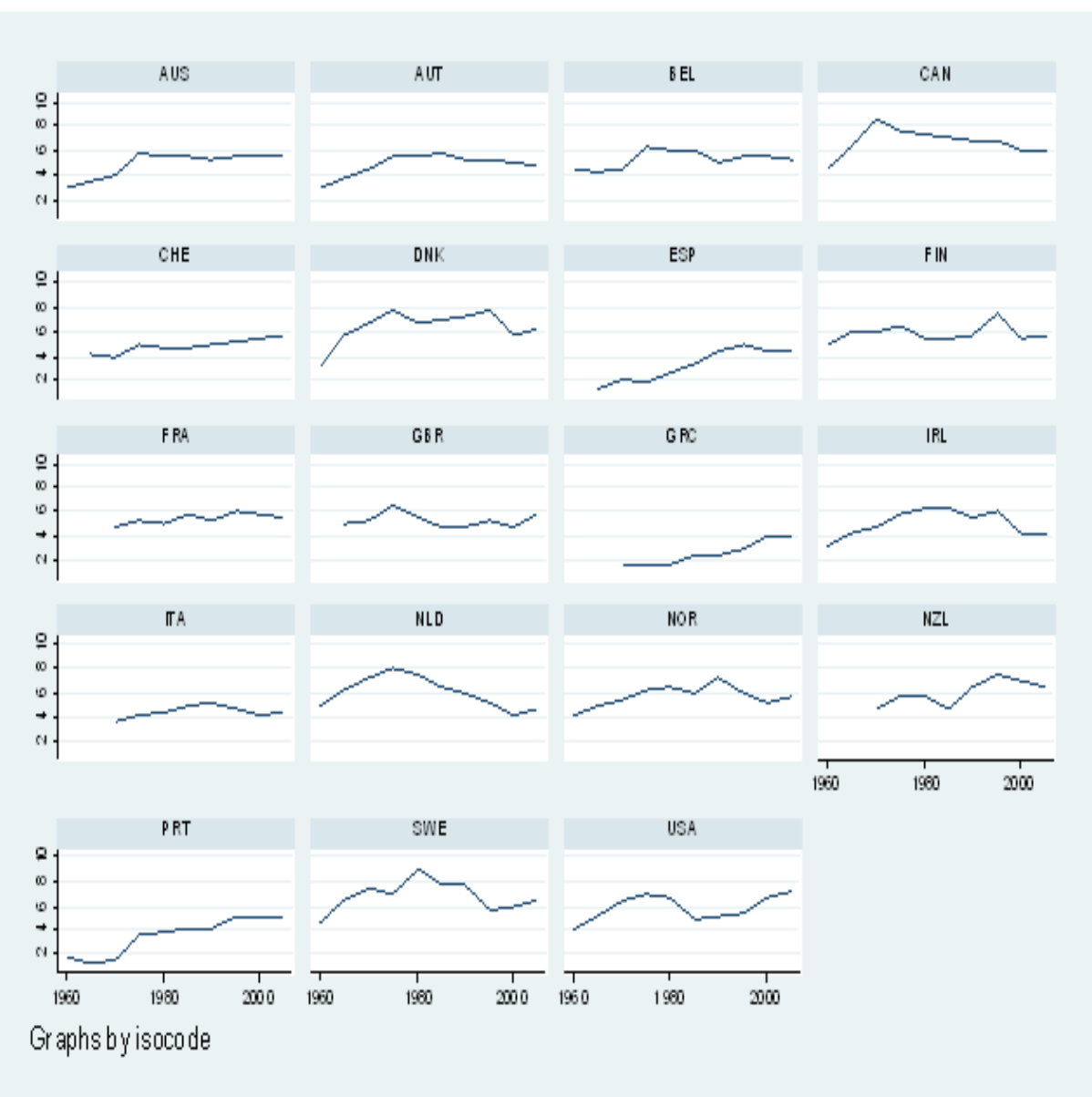

Note: $\mathrm{x}$-axis is year, and $\mathrm{y}$-axis is percentage. 
Figure 3: Total public educational expenditures per capita, 2000 prices, USD

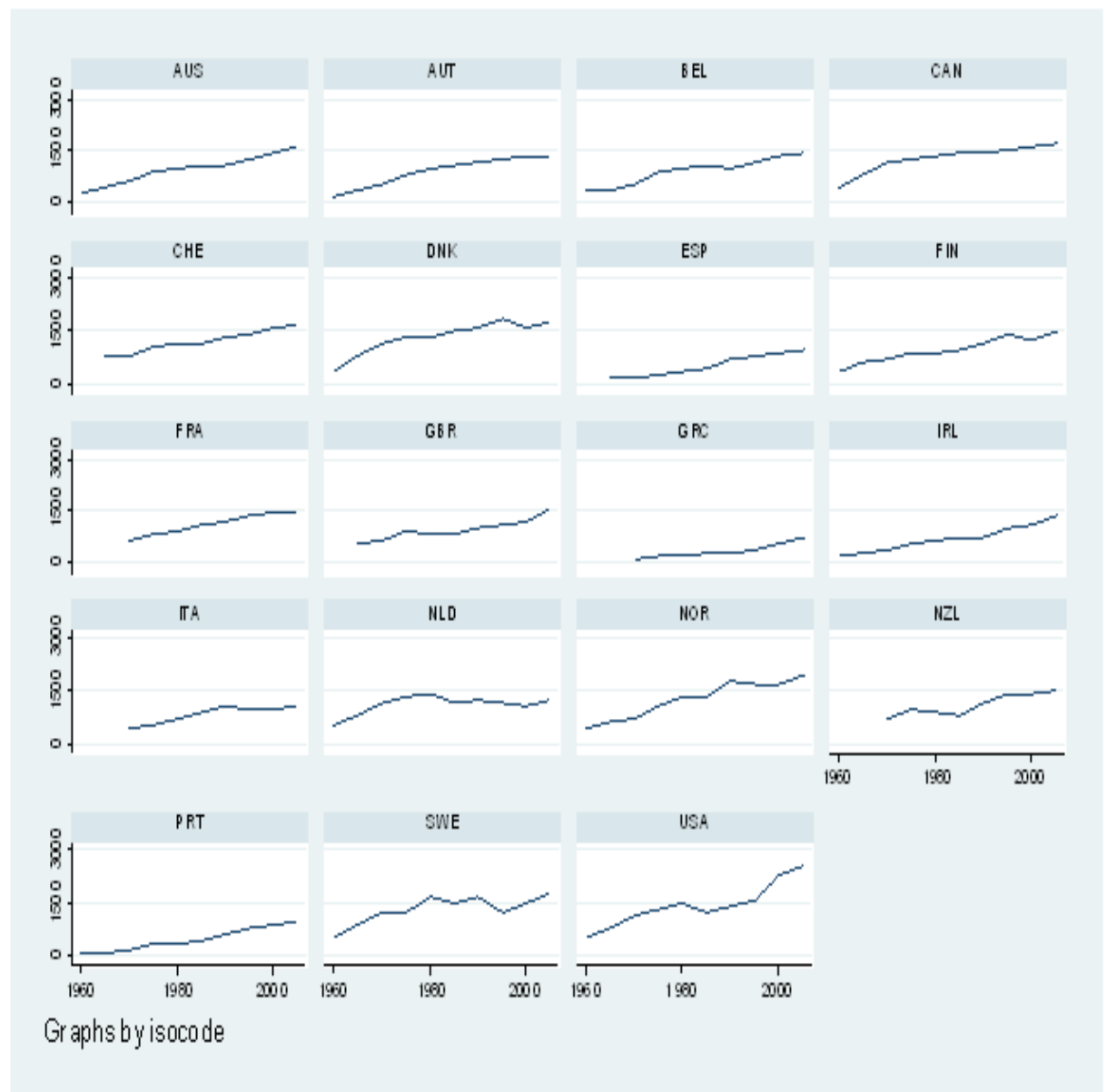

Note: $\mathrm{x}$-axis is year, and $\mathrm{y}$-axis is total public educational expenditures in 2000 constant prices of USD. 


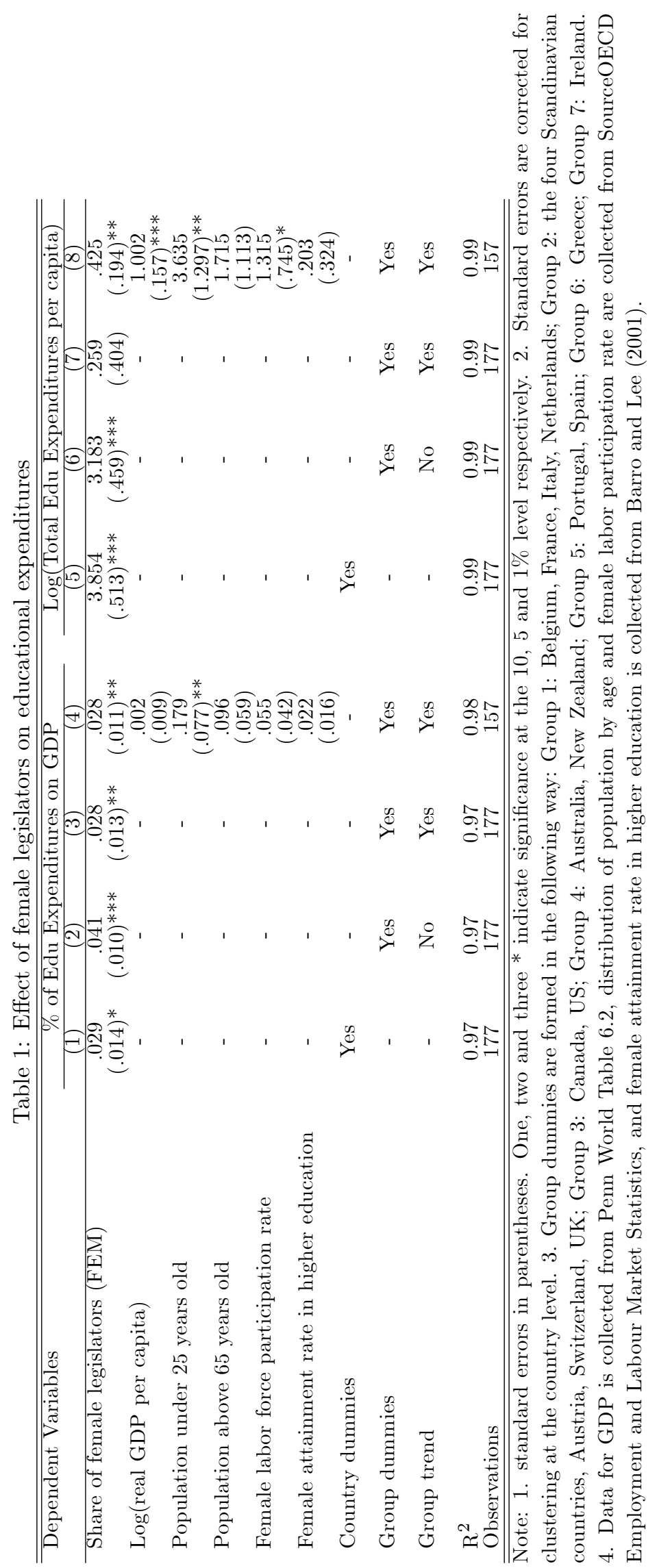




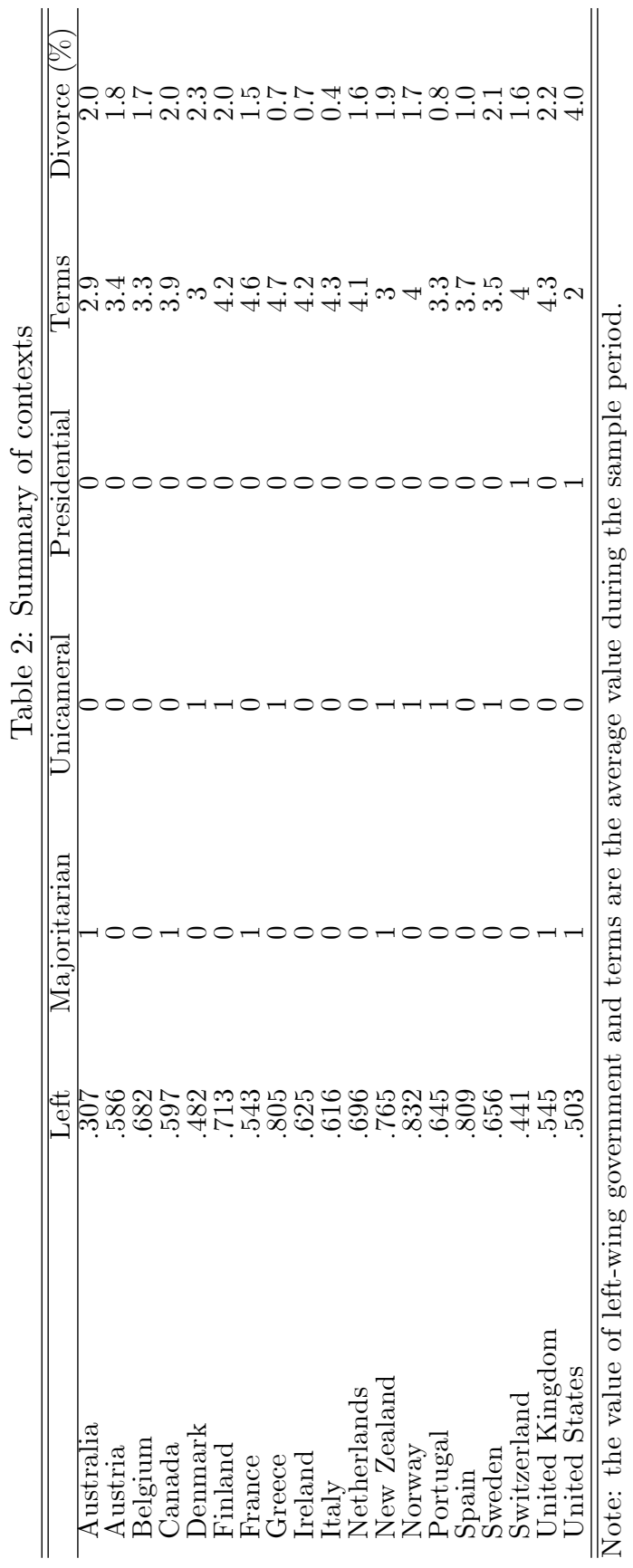




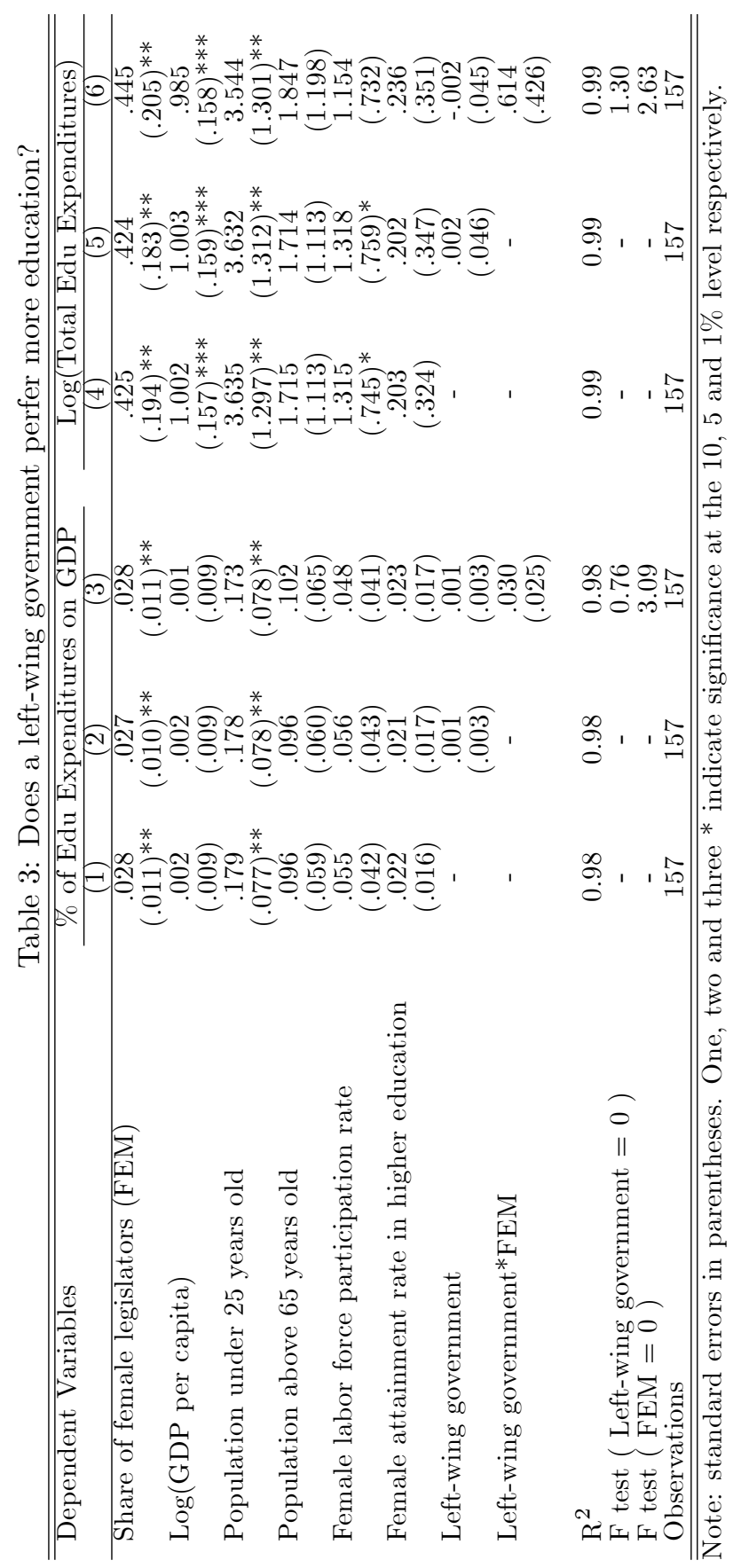




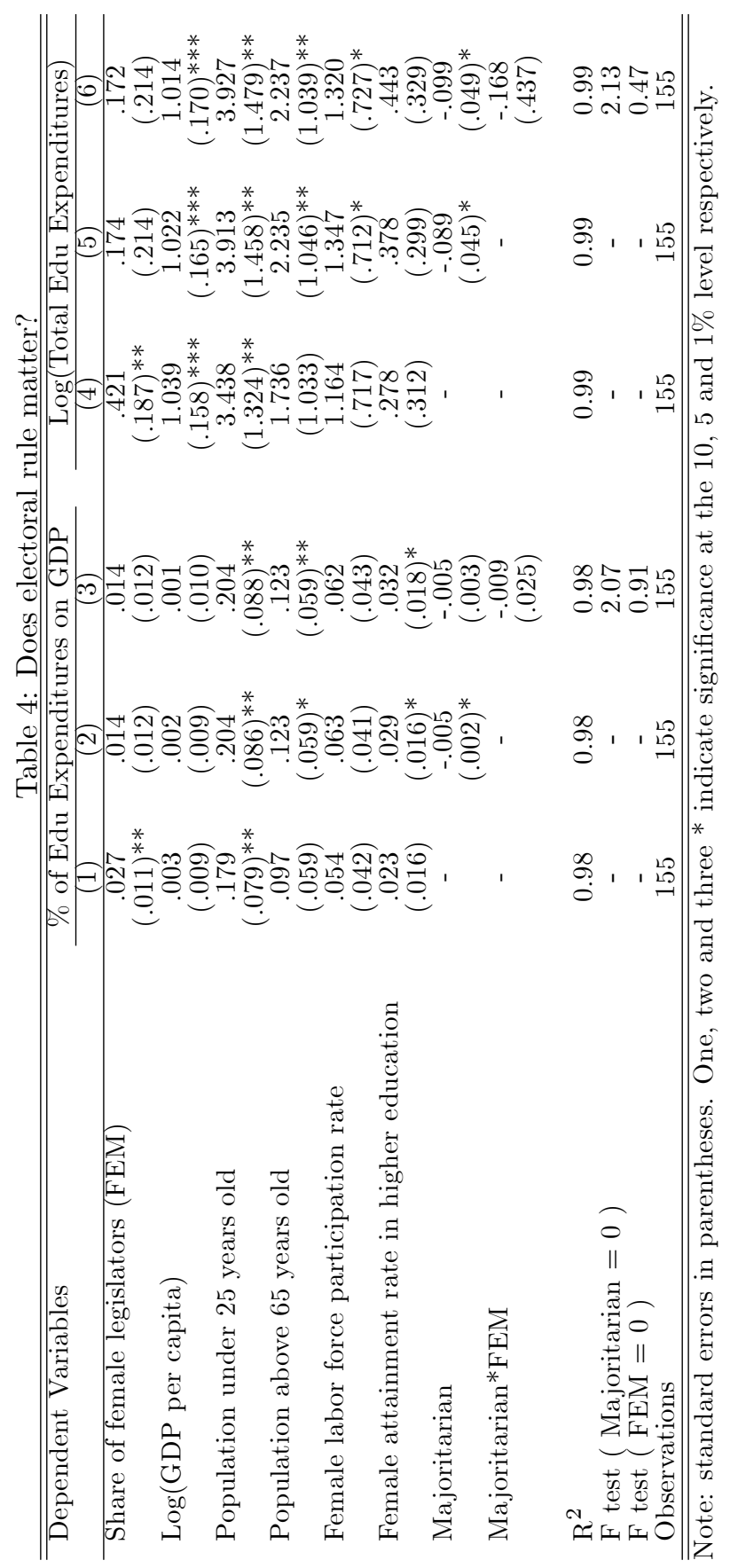




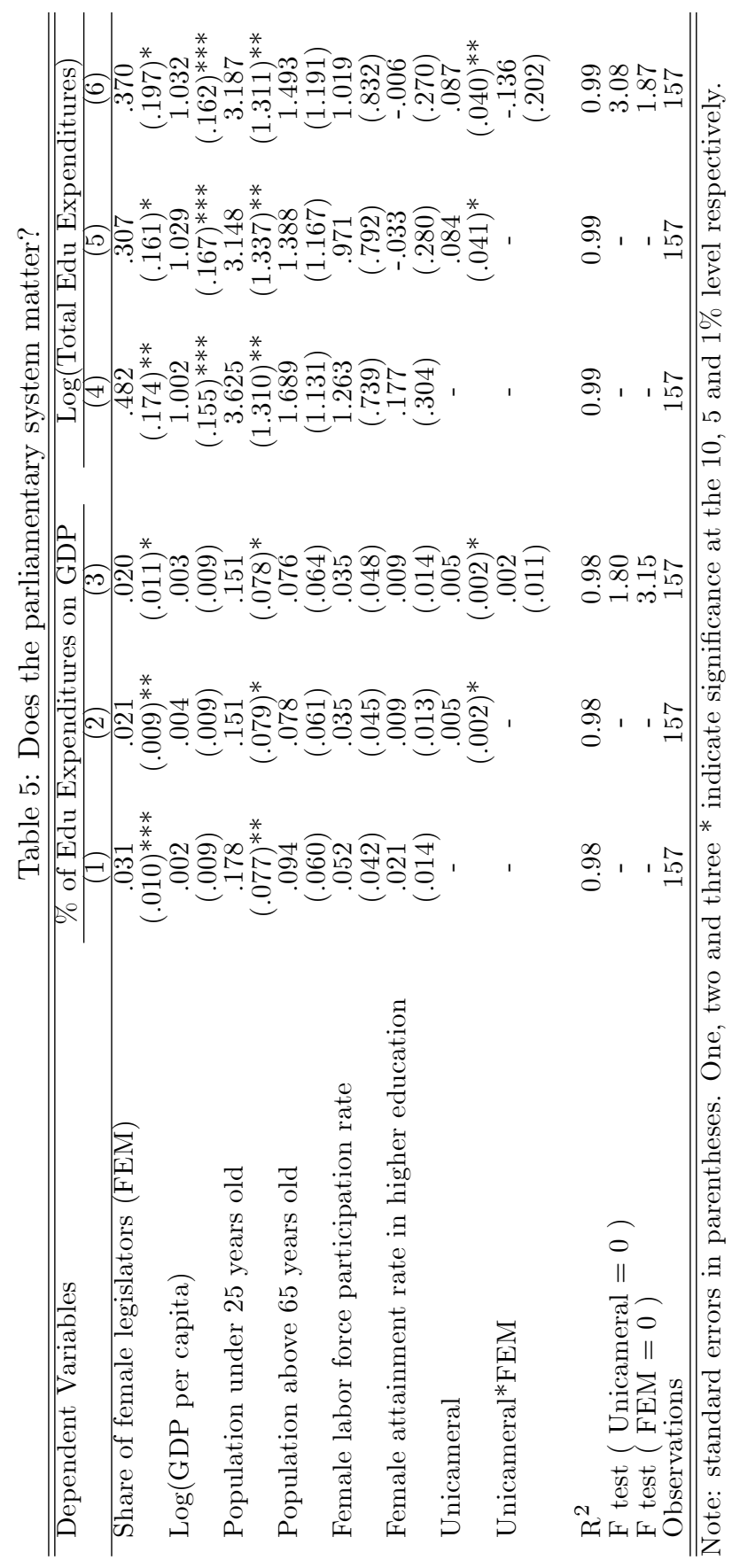




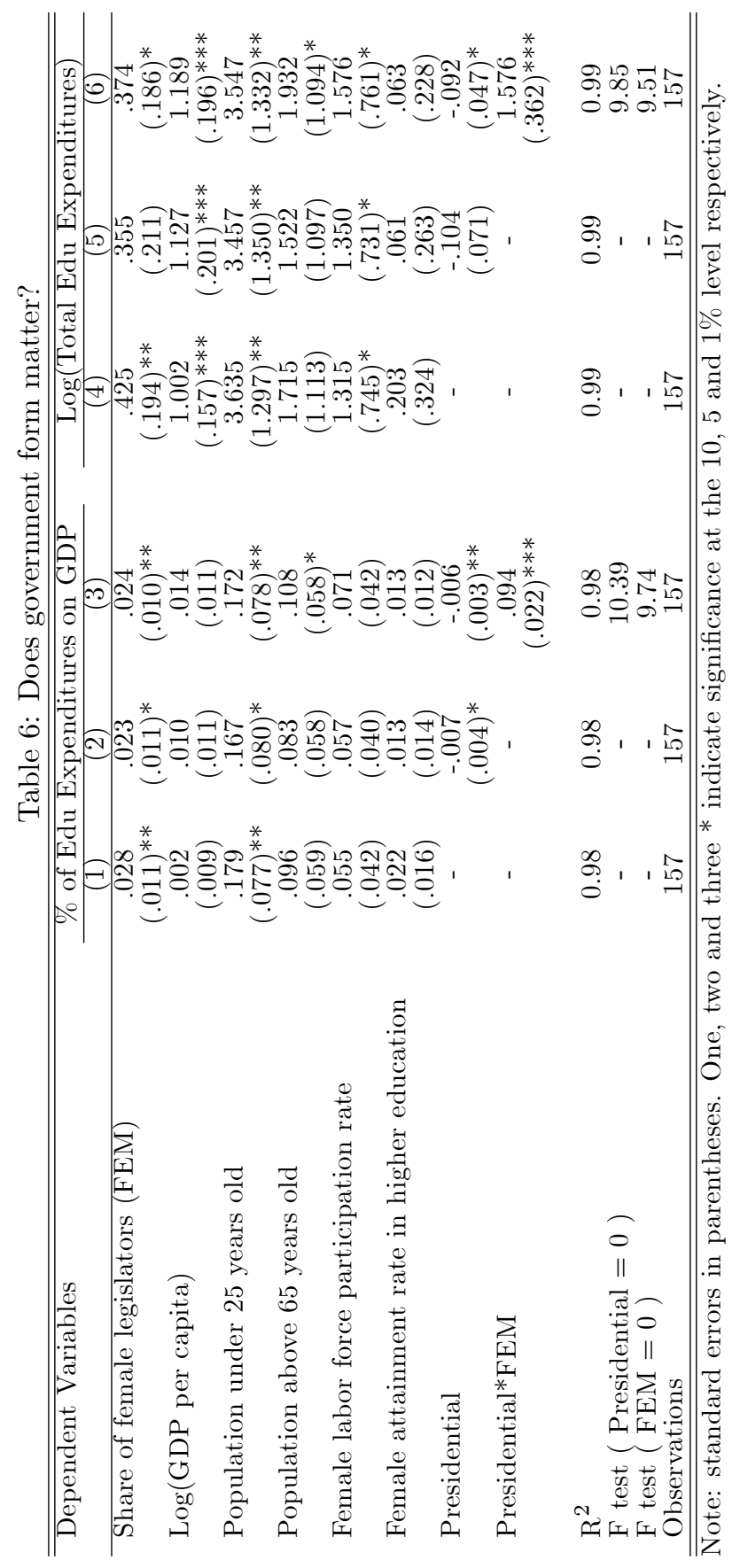




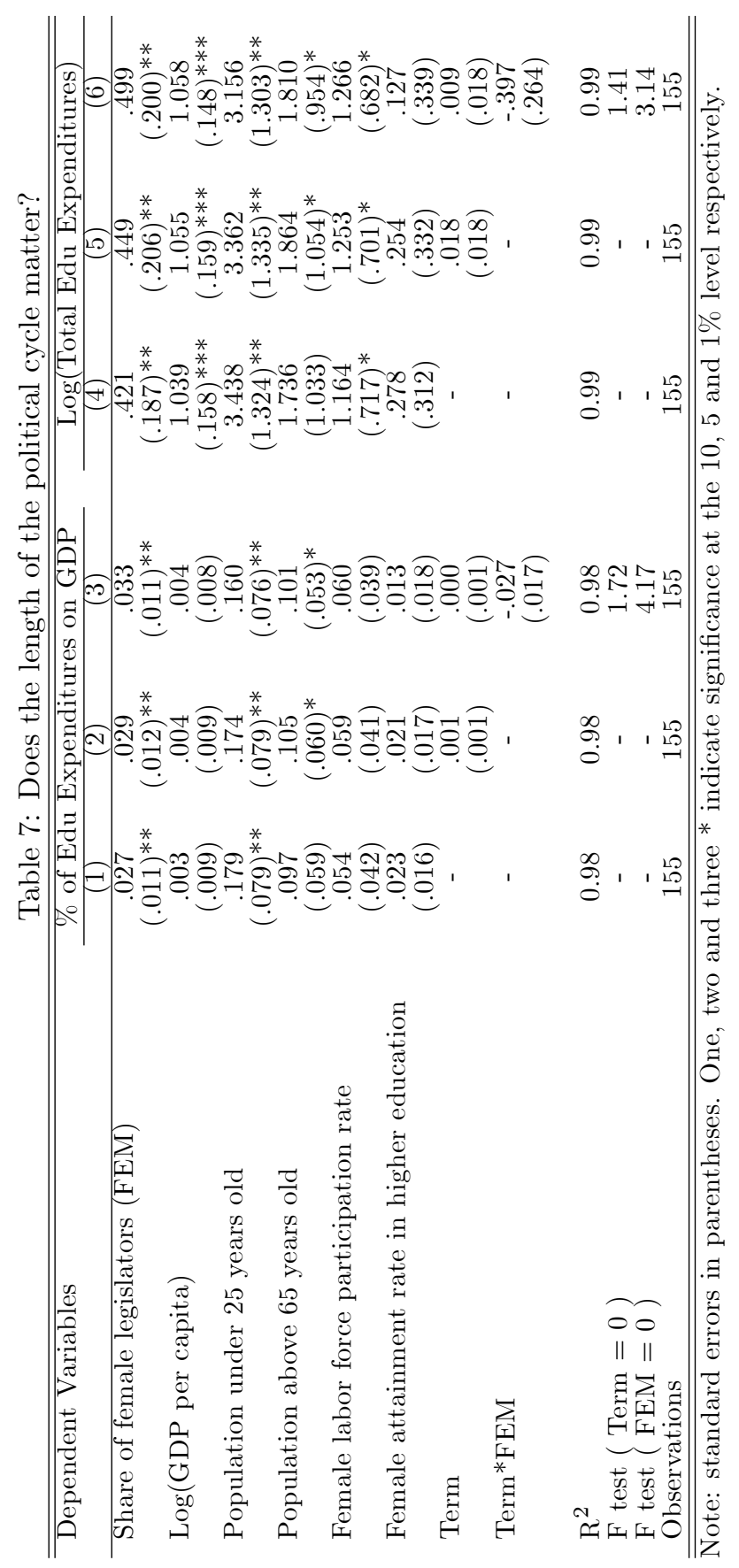




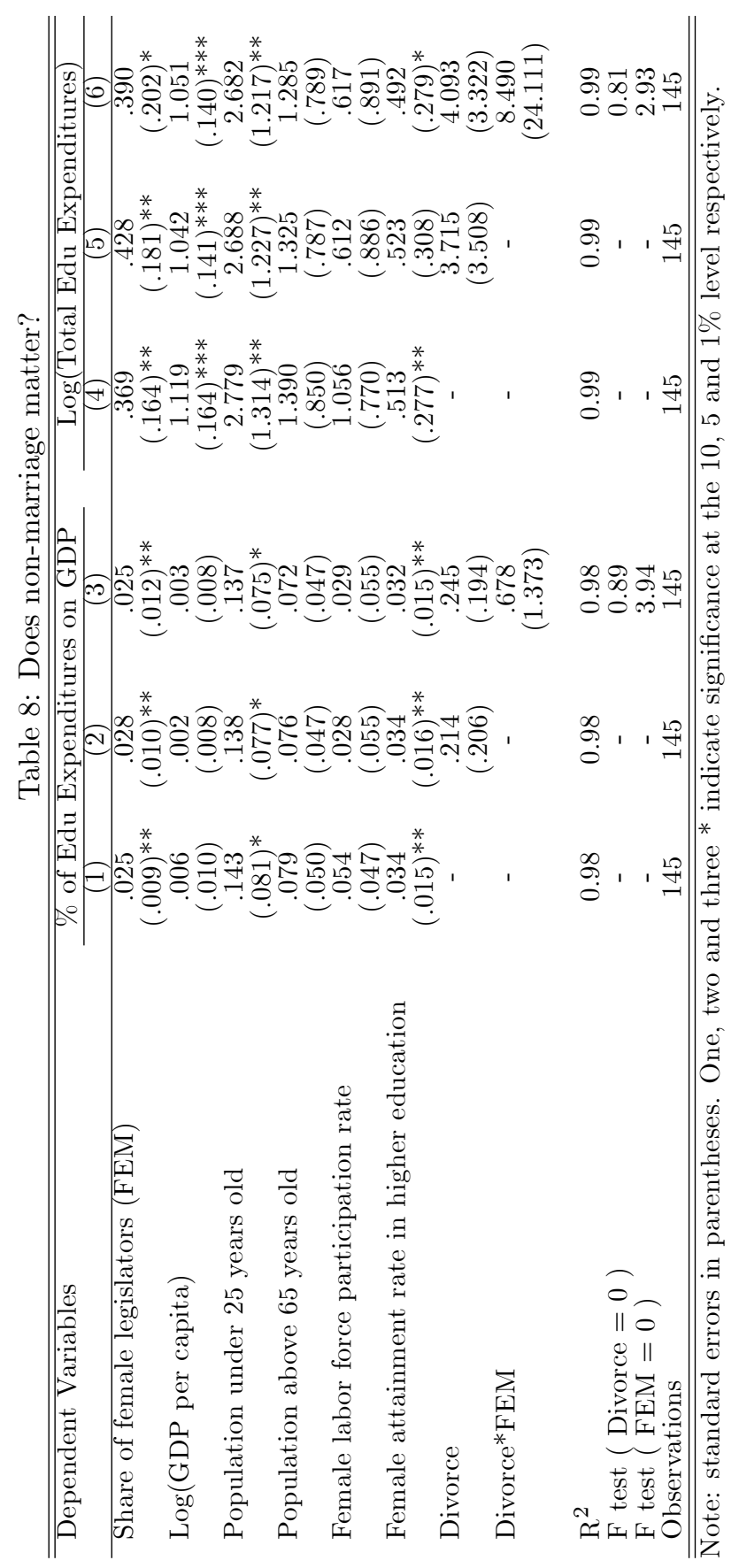

